\section{Crustal thinning and subsidence in the North Sea}

WOOD AND BARTON ${ }^{1}$ based their analysis of the North Sea Rift on gravity, refraction and well data but did not have access to multichannel reflection data. Their conclusion that the North Sea Rift subsided in response to an extension of the crust by $110 \mathrm{~km}, 50-80 \mathrm{~km}$ of which occurred during the mid-Jurassic-early Cretaceous, is at variance with reflection seismic data acquired by the petroleum industry which indicate an extension of only $20-30 \mathrm{~km}$ at the base Zechstein Salt level.

In the central North Sea, the Zechstein Salt forms part of the pre-rift sequence and its base is a regionally correlative stratigraphical and seismic marker. Thus the extension mapped at this level gives an upper limit to the amount of extension that can have occurred during the Mesozoic rifting stage of the North Sea. Amounts of extension by faulting at the base Zechstein Salt level are probably $20-25 \mathrm{~km}$, but could be as large as $30 \mathrm{~km}$. It is very unlikely, however, that a multitude of additional faults, undetectable on multichannel seismic reflection data, could account for the doubling or quadrupling of this amount as required by the stretching model ${ }^{2}$.

Average stretching factors for the central North Sea area derived from both refraction and reflection data area are as follows:

$\begin{array}{lcc}\text { Total cross-section } & \begin{array}{c}\text { Crustal } \\ \text { configuration }\end{array} & \begin{array}{c}\text { Base } \\ \text { Zechstein } \\ \text { reflector }\end{array} \\ \text { Central Graben only } & 1.25 & 1.04-1.06 \\ & 2.00 & 1.1-1.15\end{array}$

The serious descrepancies between these stretching factors suggest that crustal attenuation during the Mesozoic rifting stage of the North Sea Rift was not achieved solely by mechanical extension of the crust but that other rift-related mechanisms have also contributed to crustal thinning. Such a mechanism could be 'sub-crustal erosion' involving progressive intrusion of mantle material into the lower crust (dykes, sills) and its gradual assimilation into the upper mantle, thus causing a permanent upward displacement of the crust-mantle boundary. Such processes were probably most active during the mid-Jurassic doming stage of the central North Sea area.

Doming of rifts can be related to the ascent of the asthenosphere-lithosphere boundary (mantle plume model) and/or to the diapiric ascent of hot asthenospheric material to the base of the crust where it spreads out laterally (tensional failure model ${ }^{3,4}$ ). This latter process is the more likely mechanism to have caused the short-lived mid-Jurassic uplift of the central North Sea area. Emplacement of such an asthenolith and its subsequent cooling and resorption into the upper mantle, combined with further crustal extension, can explain the mid-Jurassic-Cretaceous subsidence pattern of the central North Sea area.

The thickness of the Cenozoic strata indicates that the thermal anomaly governing the post-rifting subsidence of the North Sea Rift was largest in the area that was domed-up during the midJurassic. On the basis of subsidence analyses, Wood and Barton postulate a $\beta$-value of 1.5 for the Central Graben while reflection data indicate a $\beta$-value of $1.1-$ 1.15. This discrepancy suggests that the magnitude of a thermal anomaly derived from the post-rifting subsidence of a rift cannot be readily related to a stretching factor. Similar discrepancies between stretching factors derived from subsidence analyses, crustal configuration and reflection data are also observed in the Witch Ground-Buchan grabens ${ }^{5,6}$ and the Viking Graben of the North Sea ${ }^{7,8}$.

The crustal configuration of the central North Sea, as defined by the available gravity and refraction data, combined with the $\beta$-value derived from the geometry of the pre-rift sediments, suggests that syn-rift crustal attenuation was achieved not only by crustal stretching but also to a large extent by 'sub-crustal erosion'. Additional geophysical data, such as deep crustal reflection profiles, are required to clarify these issues.

\section{P. A. ZIEGLER}

Shell Internationale Petroleum Mij. B.V., Postbus 162,

2501 AN, The Hague,

The Netherlands

1. Wood, R. \& Barton, P. Nature 302, 134-136 (1983).

2. McKenzie, D. P. Earth planet. Sci. Lett. 40, 25-32 (1978)

3. Turcotte, D. L. Lunar planet. Inst. Contr. 451, 5-8 (1981).

4. Neugebauer, H. W. et al. Plateau Uplift, the Rhenish Massif a Case History (Springer, Berlin, in the press).

Christie, P. A. \& Sclater, J. G. Nature 283, 729-732 (1980).

6. Smythe, D. K., Skuce, A. G. \& Donato, J. A. Nature 287, 467-468 (1980)

7. Ziegler, P. A. Geological Atlas of Western and Central Europe (Elsevier, Amsterdam, 1982)

8. Sclater, J. G. \& Christie, P. A. J. geophys. Res. 85, 3711 $3730(1980)$.

BARTON AND WOOD REPLY-Does Ziegler speak for the whole petroleum industry on this matter? Our correspondence with oil companies suggests that different estimates of extension are made from similar multichannel seismic reflection data. An example of these discrepancies is seen in the interpretation of tilted fault block structures in northern Biscay, where estimates of extension vary between $15 \%^{1}$ and $200-300 \%^{2}$. There are three possible explanations for these discrepancies:

(1) Seismic resolution of the deep basement and its faults improves with each advance in data acquisition and processing. As previously hidden faults are exposed, estimates of $\beta$ will increase.

(2) The amount of overall extension represented by the configuration of the visible part of a fault is highly controver$\mathrm{sial}^{3,4}$. The reconstruction depends on the geometric interpretation of the fault ${ }^{1,2}$, as well as the velocities used in the timedepth conversion ${ }^{3}$.

(3) The visible high-angle fault breaks may represent only the most recent generation of faulting affecting the basin. In the Basin and Range province of the United States ${ }^{5}$ and the Aegean Sea (J. A. Jackson, personal communication), earlier generations of faults, now rotated to flat lying, have taken up much of the extension. Such faults may be seismically obscure, and may also exist in the North Sea.

Any serious departure between estimates of $\beta$ from reflection methods, as opposed to refraction and subsidence studies, which still remained after the resolution of the above three points would become a real problem. If, in that case, a secondary mechanism of thinning were indicated, we would be reluctant to invoke an ad hoc process such as 'sub-crustal erosion'; a speculative concept with no quantitative basis for testing.

Western Geophysical have recently acquired two short deep reflection profiles for BIRPS (British Institutions Reflection Profiling Syndicate) along the refraction line and these are being examined.

Cambridge Earth Science contribution no. 386 .

PENNY BARTON
ROSY WOOD*
Bullard Laboratories,
Madingley Rise,
Madingley Road,
Cambridge CB3 OEZ, UK

* Present address: BP PLC, BP Research Centre, Chertsey Road, Sunbury-on-Thames, Middlesex TW16 7LN, UK.

1. Montadert, L., Roberts, D. G., De Charpal, O. \& Guennoc, P. Init. Rep. DSDP Leg 48, 1025-1060 (1979).

2. Le Pichon, X., \& Sibuet, J-C. J. geophys. Res. 86, (B5), 3708-3720 (1981).

3. Foucher, J-P., Le Pichon, X. \& Sibuet, J-C. Phil. Trans. R. Soc. A305, 27-43 (1982).

4. Bally, A. W. Phil. Trans R Soc A305, 325-336 (1982)

5. Proffett, J. M. Bull. geol. Soc. Am. 88, 247-266 (1977).

\section{A transcriptional function for repetitive ribosomal spacers in Xenopus?}

Moss $^{1}$ has recently identified and examined in vivo transcripts of the Xenopus laevis nontranscribed spacer by northern blot and $S_{1}$ nuclease analyses. $\mathrm{He}$ has proposed that "the ribosomal spacer is a loading site for RNA polymerase I, and spacer transcription is the driving force by which polymerase is delivered to the ribosomal gene pro- 